\title{
PENINGKATAN KETERAMPILAN BERBICARA BAHASA INGGRIS DENGAN METODE SUGGESTOPEDIA PADA MAHASISWA SEMESTER II-E TBI STAIN PAMEKASAN
}

\author{
S. Sumihatul Ummah MS \\ (STAIN Pamekasan/e-mail: wakasensei99@yahoo.com) \\ Eko Ariwidodo \\ (STAIN Pamekasan/email: ekarwdd@gmail.com) \\ Afifah Raihany \\ (STAIN Pamekasan/email: jihan_78ts@yahoo.com)
}

\begin{abstract}
Abstrak:
There are two problems in the result of research that will be discussed in this article. They are (1) how are the steps of the implementation of suggestopedia method in learning speaking English at the second semester students of E class TBI STAIN Pamekasan and (2) How are the increasing of speaking English skill for the second semester students of E class TBI STAIN Pamekasan in learning speaking English by using the suggestopedia method. The research method is classroom action research by using research strategy of Kemmis and Mc Taggert Model which consist of four (4) steps, namely planning, acting, observing, and reflecting. The result of research provided that classically for the $1^{\text {st }}, 2^{\text {nd }}$, and $3^{\text {rd }}$ cycle indicated the increasing of students learning completeness scores, each of them are $38.23 \%, 67.54 \%$, and $82.35 \%$. While the students performance for each aspects are increasing from the $1^{\text {st }}$ cycle up to $3^{\text {rd }}$ cycle. The students performance of speaking English activities in the classroom from each aspects that more appear was grammar with score $85.2 \%$. for the $2^{\text {nd }}$ cycle was comprehensibility with score $88.2 \%$ and vocabulary with score $88.2 \%$, and for the $3^{\text {rd }}$ cycle that more appear was fluency with score $91.2 \%$. Besides, for the frequency percentage of students performance from each cycles are more increasing, by the $1^{\text {st }}$ cycle 55\% (enough), the $2^{\text {nd }}$ cycle 70\% (good), and the $3^{\text {rd }}$ cycle $85 \%$ (very good). Finally, the suggestopedia method in learning speaking English can increase the result of students learning. In fact, the students look like be enthusiastic in learning speaking English. The students were active to joint with this subject from each cycle. By the good atmosphere, conducive situation of the classroom, and soft music made the students to be relax in learning the subject. It also was increase imagination, concentration, and liveliness for the students.
\end{abstract}

\section{Keywords:}

Speaking English, Suggestopedia

Pendahuluan

Keterampilan 
keterampilan bahasa yang perlu dikuasai dengan baik. Keterampilan ini merupakan suatu indikator terpenting bagi keberhasilan seseorang untuk bisa berbahasa inggris dengan benar dan lancar. terutama bagi generasi muda pada umumnya dan mahasiswa pada khususnya dalam belajar bahasa Inggris. Tarigan menyatakan bahwa "Jika seseorang menguasai suatu bahasa, secara intuitif ia mampu berbicara dalam bahasa tersebut". ${ }^{1}$ Pendapat ini jelas mengindikasikan bahwa keterampilan berbicara mengisyaratkan seseorang mengetahui suatu bahasa. Dengan penguasaan keterampilan berbicara yang baik, mahasiswa dapat mengomunikasikan ide-ide mereka, baik di kelas maupun dengan penutur asing, dan juga menjaga hubungan baik dengan orang lain. Keterampilan ini sangat terkait dengan pelafalan, gramatika, kosakata, diskursus, keterampilan mendengarkan, dan sebagainya.

Pentingnya memiliki keterampilan berbicara bahasa inggris sebagai alat komunikasi dan alat berpikir terlihat juga pada mata kuliah Speaking English. Pada umumnya, mahasiswa masih mengalami kesulitan untuk menyampaikan gagasan, pikiran, pertanyaan dan sebagainya dengan menggunakan bahasa Inggris dengan benar dan lancar. ${ }^{2}$ Hal ini sering terjadi

${ }^{1}$ Tarigan, Henry Guntur.2009. Metode Pengajaran Bahasa.Bandung: Angkasa Bandung. HIm 53.

${ }^{2}$ Pre-research. Meeting semi formal dengan dosen pengampu matakuliah Speaking karena adanya banyak faktor misalnya tidak percaya diri, takut, malu, dan kadang merasa takut keliru grammar dan vocab ketika mengungkapkan ideidenya. Faktor-faktor inilah yang membuat mereka tidak aktif dalam belajar berbicara bahasa inggris. Problematika inilah yang juga dialami oleh para mahasiswa semester II-E TBI STAIN Pamekasan. Kurang lebih 75\% mahasiswa semester II-E tersebut bermasalah dengan keterampilan Speaking English dalam proses pembelajaran dikelas. ${ }^{3}$ Suasana belajar mahasiswa menjadi pasif dan kurang bersemangat. Hal tersebut diakibat karena tidak adanya keberanian pada diri mahasiswa untuk mengemukakan pendapat atau bertanya dengan menggunakan bahasa inggris secara lisan. ${ }^{4}$ Oleh karena itulah, kondisi nyata di atas harus segera diatasi. Melalui tindakan kelas, langkah-langkah praktis untuk mengatasi keadaan itu dilaksanakan dan pada gilirannya dapat meningkatkan keterampilan berbicara bahasa inggris mahasiswa.

Berdasarkan fenomena di atas, peneliti yang juga dosen pada program studi TBI STAIN Pamekasan berkolaborasi dengan dosen pengampu matakuliah Speaking English pada semester II-E TBI STAIN Pamekasan merasa bertanggung jawab dan

English semester II-E TBI STAIN Pamekasan pada tanggal 3 April 2013 ${ }^{3}$ Ibid

${ }^{4}$ Pre-research pada mahasiswa semester II-E TBI STAIN Pamekasan pada tanggal 5 April 2013. 
tertantang untuk memperbaiki suasana kelas agar lebih aktif dan bersemangat. Keadaan inilah yang mendorong peneliti untuk melakukan penelitian tindakan kelas untuk mengatasi kesulitan dalam pembelajaran Speaking English agar mahasiswa memiliki keterampilan dan keberanian berkomunikasi dengan menggunakan bahasa inggris yang benar dan lancar. Metode yang digunakan adalah dengan menerapkan metode suggestopedia.

Metode suggestopedia ini menciptakan atmosfir kelas yang kondusif dengan ruang belajar ditata supaya santai. Selain itu, pada tiap pelajaran diberikan pula latar belakang musik. ${ }^{5}$ Mahasiswa diajak melakukan relaksasi untuk menenangkan pikirannya. ${ }^{6}$ Metode suggestopedia ini menyarankan pula agar dosen selalu berupaya menghilangkan sugesti negatif atau rasa takut yang dapat menghambat belajar; misalnya perasaan tidak mampu, takut membuat kesalahan, resah akan hal yang baru atau tidak dikenal. $^{7}$ Yang penting dikembangkan bahwa belajar itu mudah dan menyenangkan. Dengan mendobrak rasa takut yang menghambat diri mahasiswa, dihasilkan hypermnesia atau pengingatan yang meningkat juga kemampuan komunikatif yang tidak

${ }^{5}$ Larsen-Freeman,D. 1986. Techniques and Principles in Language Teaching. Oxford: Oxford University Press. HIm79.

${ }^{6}$ Ibid

${ }^{7}$ Setiyadi, A. Bambang, dkk. 2008. TEFL terhambat. ${ }^{8}$ Peneliti berpendapat bahwa metode suggestopedia adalah salah satu metode yang tepat untuk diterapkan dalam proses pembelajaran Speaking English ini agar supaya mahasiswa termotivasi dan berani untuk dapat berbicara dengan menggunakan bahasa inggris tanpa terbebani dengan perasaan takut atau malu. Sehingga suasana kelas akan lebih hidup dan akan tercipta atmosfir kelas yang kondusif dengan pemilihan ruangan yang menunjang proses pembelajaran Speaking English. Dengan demikian, keterampilan berkomunikasi bahasa inggris mahasiswa juga dapat ditingkatkan.

Seiring dengan adanya fenomena yang telah dijelaskan diatas ini, masalah pokok yang dikaji dari hasil penelitian ini adalah (1) Bagaimana langkah-langkah penerapan metode suggestopedia dalam pembelajaran Speaking English pada mahasiswa semester II-E TBI STAIN Pamekasan dan (2) Bagaimana peningkatan keterampilan berbicara bahasa inggris mahasiswa semester II-E TBI STAIN Pamekasan dalam pembelajaran Speaking English dengan menggunakan metode suggestopedia. Sedangkan tujuan dari penelitian ini adalah untuk mengetahui langkah-langkah penerapan metode suggestopedia dalam pembelajaran Speaking English dan mengetahui peningkatan keterampilan berbicara bahasa inggris mahasiswa semester II-E TBI STAIN Pamekasan

${ }^{8}$ Ibid 
dalam pembelajaran Speaking English dengan menggunakan metode suggestopedia. Sedangkan hipotesa penelitian tindakan kelas ini adalah "Jika dalam mata kuliah Speaking English pada mahasiswa semester II-E diterapkan metode suggestopedia maka aktivitas dalam keterampilan berbicara bahasa inggris para mahasiswa dapat ditingkatkan".

\section{Metode Penelitian}

Penelitian ini merupakan penelitian tindakan kelas (PTK) karena peneliti ingin melakukan tindakan perbaikan, peningkatan, dan juga melakukan suatu perubahan ke arah yang lebih baik dari sebelumnya pada matakuliah berbicara bahasa inggris (Speaking English) sebagai upaya pemecahan masalah dalam proses belajar mengajar di kelas. Sedangkan rancangan penelitian ini menggunakan dua rancangan sekaligus yaitu kuantitatif dan kualitatif. Rancangan kuantitatif untuk mengumpulkan dan menganalisis data yang berupa angka, misalnya analisis data pengelolaan pembelajaran yang dilakukan dosen pada tiap siklusnya, persentase kinerja mahasiswa, dan persentase ketercapaian kinerja mahasiswa. Sedangkan rancangan kualitatif untuk mengumpulkan dan menganalisis data yang digambarkan dengan deskripsi, misalnya mendeskripsikan hasil observasi langsung (seperti suasana kelas, keberanian mahasiswa, sikap self-confidence mahasiswa, keaktifan mahasiswa, kerjasama antar mahasiswa, motivasi belajar mahasiswa), jurnal kegiatan dari peneliti dan dosen sejawat. ${ }^{9}$ Strategi penelitian ini menggunakan model Kemmis dan McTaggert (model siklus) yang terdiri dari 4 (empat) langkah, yaitu: Rencana (Planning), Tindakan (Acting), Observasi (Observing), dan Refleksi (Reflecting). ${ }^{10}$

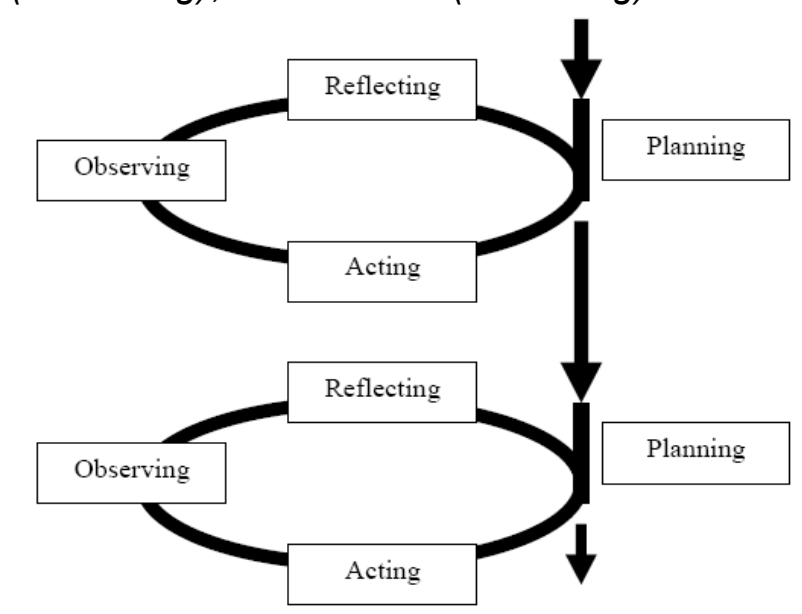

Gambar 1. Siklus dalam penelitian PTK model Kemmis \& Mc'Taggart

\section{Rencana (planning).}

Rencana adalah

tahapan menyiapkan strategi yang akan dikembangkan dengan seluruh media dan materi pembelajarannya. ${ }^{11}$ Rencana tindakan yang akan dilakukan untuk memperbaiki, meningkatkan atau mengubah perilaku dan sikap sebagai solusi, meliputi: (1) observasi awal, (2) menyusun rencana pelaksanaan pembelajaran (RPP), (3) menyusun

${ }^{9}$ Latief, Adnan M. 2009. Penelitian Tindakan Kelas Pembelajaran Bahasa Inggris. Malang: Universitas Negeri Malang. HIm. 16.

${ }^{10}$ Latief, Adnan M. 2011. Research Methods on Language Learning an Introduction. Malang: Universitas Negeri Malang. HIm 145-146. ${ }^{11}$ Ibid. 
instrumen observasi, dan (4) menentukan jadwal pelaksanaan.

\section{Tindakan (Acting).}

Tindakan merupakan tahap pelaksanaan strategi yang telah dipersiapkan. $^{12}$ Pada tahap ini, peneliti melaporkan langkah-langkah penerapan metode suggestopedia dalam matakuliah Speaking English pada mahasiswa semester II-E TBI STAIN Pamekasan yang telah disiapkan, meliputi:

mendeskripsikan semua kegiatan yang dilakukan berdasarkan strategi yang telah disiapkan,

melaksanakan kegiatan/tindakan sesuai rencana pelaksanaan pembelajaran (RPP), dan (3) melakukan pengelolaan dan pengendalian.

\section{Observasi (Observing).}

Observasi adalah kegiatan pengumpulan data yang berkaitan dengan peristiwa pembelajaran yang terkait dengan upaya pemecahan masalah dan strategi pembelajaran yang sedang dikembangkan. Yang diamati adalah peristiwa-peristiwa yang menjadi indikator keberhasilan (criteria of success) atau ketidakberhasilan pemecahan masalah dan pengembangan strategi yang sedang dikembangkan. Kriteria (indikator yang menjadi penanda) untuk menentukan bahwa strategi yang dikembangkan telah berhasil memecahkan masalah yang sedang diupayakan pemecahannya seperti yang tertulis dalam tahap perencanaan harus menjadi fokus pengamatan. Dalam hal ini, tahap observasi dalam PTK adalah seperti tahap pengumpulan data dalam penelitian selain PTK, maka dalam tahap ini juga dibahas (1) data yang akan dikumpulkan, (2) instrumen pengumpulan data yang akan dipakai, (3) sumber data yang akan digali, dan (4) teknik pengumpulan data yang akan digunakan. ${ }^{13}$ Keempat tahap tersebut akan dijelaskan sebagai berikut:

\section{a. Data PTK}

Data yang dipakai dalam penelitian ini adalah data kualitatif dan kuantitatif. Data kualitatif misalnya data dari hasil wawancara, dokumentasi, jurnal kegiatan pembelajaran Speaking English, dan rekaman. Sedangkan data kuantitatif berupa angka atau nilainilai yang diperoleh dari nilai hasil observasi dan tes speaking English.

\section{b. Instrumen PTK}

Instrumen penelitian ini adalah observasi, tes, wawancara, dan dokumentasi.

\section{c. Sumber Data PTK}

Sumber data penelitian ini adalah dosen matakuliah Speaking English, dosen sejawat, seluruh mahasiswa semester II-E TBI STAIN Pamekasan yang berjumlah 34 orang.

\section{d. Teknik Pengumpulan Data PTK}


Teknik pengumpulan data PTK ini menyesuaikan data yang telah direncanakan untuk dikumpulkan dengan menggunakan instrumen yang telah dipersiapkan. ${ }^{14}$ Teknik pengumpulan data dalam penelitian ini yaitu:

\section{Data kuantitatif menggunakan} teknik tes dan observasi.

Tes ini merupakan tes evaluasi Speaking English yang dilaksanakan setiap akhir pertemuan pada setiap putaran. Dari tes ini akan diketahui nilai kinerja mahasiswa dan ketercapaian kinerja mahasiswa dalam pembelajaran Speaking English. Dalam hal ini, peneliti dapat mengetahui tingkat perkembangan keterampilan berkomunikasi mahasiswa dari setiap tahap kegiatan penelitian tindakan yang dilakukan. Sedangkan pada Teknik observasi, peneliti akan memperoleh data dari observer (dosen sejawat) berupa nilai dari lembar pengelolaan pembelajaran Speaking English yang dilakukan oleh dosen.

2. Data kualitatif menggunakan teknik wawancara dan dokumentasi.

Pada Teknik wawancara, peneliti memperoleh data dari hasil wawancara dengan dosen matakuliah Speaking English tentang situasi pembelajaran
Speaking English pada mahasiswa semester II-E TBI STAIN Pamekasan sebelum dan setelah diadakan tindakan di kelas tersebut sehingga tingkat keaktifan kelas juga dapat dirasakan oleh para dosen sejawat. Sedangkan pada Teknik dokumentasi, peneliti memperoleh data dari foto dan hasil rekaman dalam proses pembelajaran Speaking English pada mahasiswa semester II-E TBI STAIN Pamekasan.

4. Refleksi (Reflecting).

Refleksi adalah kegiatan menganalisis hasil pengamatan untuk menentukan sudah sejauh mana pengembangan strategi yang sedang digunakan telah berhasil memecahkan masalah dan apabila belum (sepenuhnya) berhasil, faktor apa saja yang menjadi penghambat kekurang berhasilan tersebut. Kegiatan refleksi ini meliputi kegiatan analisis data. Refleksi bertujuan untuk menilai mana kriteria tersebut yang belum tercapai dan apa penyebab belum tercapainya kriteria tersebut. Kriteria yang belum tercapai tersebut serta faktor penyebabnya menjadi masukan pada siklus berikutnya. ${ }^{15}$ Pada tahap refleksi ini, peneliti menganalisa data dari:

1. Lembar Pengamatan

Pengelolaan Pembelajaran 
Pada lembar pengelolaan pembelajaran, setiap aspek yang diamati dinilai dengan skala skor 1 s.d 4 dengan penafsiran angkaangka tersebut adalah $1=$ kurang, 2 = cukup, 3 = baik, $4=$ sangat baik. ${ }^{16}$ Kemudian pada tahap akhir skor tersebut dirata-rata, selanjutnya nilai rata-rata tersebut dikonfirmasikan dengan kriteria sebagai berikut:

$1,00 \leq x<1,70=$ Kurang

$1,70 \leq x<2,60=$ Cukup

$2,60 \leq x<3,51=$ Baik

$3,51 \leq x<4,00=$ Sangat baik

Keterangan: $x=$ rata-rata kemampuan dosen dalam mengelola pembelajaran Speaking English pada setiap aspek. ${ }^{17}$ Kemampuan dosen dalam mengelola pembelajaran dikatakan efektif bila rata-rata setiap aspek dalam mengelola pembelajaran masuk kriteria baik atau sangat baik.

\section{Analisis Lembar Penilaian} Kinerja Mahasiswa

Kinerja siswa selama kegiatan pembelajaran dapat dikonversikan dalam bentuk nilai yaitu persentase tiap aspek diperoleh dari jumlah aspek yang muncul dibagi dengan jumlah siswa dalam kelas dikalikan $100 \%{ }^{18}$ Rumus kinerja mahasiswa sebagai berikut:

${ }^{16}$ Depdiknas. 2002. Kurikulum Berbasis Kompetensi. Jakarta Pusat: Pusat Kirikulum Balitbang Diknas.

17 Ibid
${ }_{18}$ Asep Jihad, Evaluasi Pembelajaran, Yogyakarta: Multi Pressindo, 2008, hlm.34
$\%$ tiap aspek $=\Sigma$ aspek yang muncul $/ \Sigma$ seluruh siswa $\times 100 \%$.

Dari hasil analisis dilanjutkan dengan membuat tabel frekuensi mahasiswa pada masing-masing aspek setiap siklusnya seperti di bawah ini:

Tabel Frekuensi Siswa pada Tiap Siklus

\begin{tabular}{|c|l|l|l|l|l|l|l|}
\hline \multirow{2}{*}{$\begin{array}{c}\text { Sko } \\
r\end{array}$} & \multirow{2}{*}{ Kategori } & \multicolumn{2}{|c|}{ Siklus I } & \multicolumn{2}{|c|}{$\begin{array}{c}\text { Siklus } \\
\text { II }\end{array}$} & \multicolumn{2}{|c|}{$\begin{array}{c}\text { Siklus } \\
\text { III }\end{array}$} \\
\hline & & F & $\%$ & F & $\%$ & F & $\%$ \\
\hline 1 & Kurang & & & & & & \\
\hline 2 & Cukup & & & & & & \\
\hline 3 & Baik & & & & & & \\
\hline 4 & $\begin{array}{l}\text { Sangat } \\
\text { baik }\end{array}$ & & & & & & \\
\hline
\end{tabular}

Standar ketercapaian kinerja mahasiswa dalam pembelajaran Speaking English jika mahasiswa memperoleh nilai $65 \%$ dari total skor tertinggi (32) yaitu 21 sehingga dapat dituliskan bahwa mahasiswa telah mencapai standar ketercapaian kinerja mahasiswa jika $21 \leq x \leq 32$. Sedangkan standar ketercapaian kinerja mahasiswa secara klasikal diperoleh jika terdapat $85 \%$ mahasiswa telah mencapai standar ketercapaian kinerja mahasiswa yang dihitung dengan rumus: $^{19}$

Ketercapaian kelas $=$ Jumlah Siswa yg lulus/ jumlah siswa $\mathrm{x}$ $100 \%$

Dari hasil analisis di atas dilanjutkan dengan membuat grafik ketercapaian kelas pada setiap siklus.

${ }^{19}$ Mukhlis. 2000. Penelitian Tindakan Kelas. Pusat Sains MIPA Unesa 


\section{Ketuntasan Kelas}

a. Ketuntasan mahasiswa

Daya Serap = Jumlah Skor jawaban yang benar/ jumlah skor total x 100 .

Keterangan: siswa secara individual dianggap tuntas belajar bila daya serap mahasiswa mencapai skor 65 .

b. Ketuntasan kelas

Ketuntasan $=$ jumlah siswa yang tuntas/jumlah siswa $\mathrm{x}$ $100 \%$

Keterangan: mahasiswa secara klasikal dianggap tuntas belajar bila ketuntasan kelas mencapai $85 \%$ dari jumlah siswa yang mencapai skor daya serap minimal $65 .^{20}$

\section{Hasil Penelitian dan Pembahasan}

\section{A. Hasil Penelitian}

Hasil penelitian tindakan kelas ini disusun berdasarkan hasil pengamatan, catatan kejadian selama proses pembelajaran berbicara bahasa inggris (Speaking English) melalui metode suggestopedia, dan beberapa komentar tanggapan dari para rekan pengamat dan dosen sejawat.

\section{Langkah-Langkah Penerapan} Metode Suggestopedia Dalam Pembelajaran Speaking English.

Pada hasil penelitian ini, peneliti mendeskripsikan langkahlangkah penerapan metode suggestopedia

dalam pembelajaran Speaking English pada mahasiswa semester II-E TBI STAIN Pamekasan yang dilakukan dalam tiga siklus dan tiap-tiap siklusnya mempunyai alokasi waktu 100 menit. Setiap siklus mencakup 4 tahapan, yaitu: Perencanaan (Planning), Tindakan (Acting), Pengamatan (Observing), dan Refleksi (Reflecting) sebagai berikut:

\section{$>$ Siklus ke-I}

- Topik : Personal identity

- Metode : Suggestopedia

- Teknik : Choose a new identity

- Hari/tgl/bln/thn: Jumat, 31-Mei2013

-Instruktur : Abd.Wafi \& S. Sumihatul Ummah

-Observer : Afifah Raihany \& Eko Ariwidodo

- Waktu : 2x50 menit

\section{Perencanaan (Planning)}

Pada tahap ini peneliti mempersiapkan semua perlengkapan yang diperlukan selama kegiatan belajar mengajar Speaking English dengan menggunakan metode suggestopedia.

Perlengkapan tersebut terdiri dari Rencana Pelaksanaan Pembelajaran (RPP), students worksheet, lembar observasi, lembar evaluasi, dan media atau alat-alat yang digunakan dalam 


\begin{abstract}
pembelajaran Speaking
English. Rencana tindakan yang dilakukan oleh peneliti ini bertujuan untuk memperbaiki atau meningkatkan keterampilan berbicara mahasiswa semester II-E TBI STAIN Pamekasan. Adapun indikator yang ingin dicapai adalah mahasiswa dapat memperkenalkan indentitas diri sendiri atau orang lain dengan menggunakan bahasa inggris yang benar dan lancar sesuai dengan topik yang telah ditentukan oleh dosennya, seperti: nama, alamat, asal negara, bahasa yang digunakan, pekerjaan, dan sebagainya.
\end{abstract}

\section{Pelaksanaan Tindakan} (Acting)

Pada tahap pelaksanaan tindakan ini peneliti secara kolaboratif dengan dosen pengampu mata kuliah Speaking English menerapkan metode suggestopedia dalam pembelajaran Speaking English pada mahasiswa semester II-E TBI STAIN Pamekasan. Sedangkan observernya adalah ibu Afifah Raihany dan bapak Eko Ariwidodo (teman/dosen sejawat pada TBI STAIN Pamekasan). Tugas dari $\begin{array}{lrr}\begin{array}{l}\text { observer di sini } \\ \text { mengamati }\end{array} & \begin{array}{r}\text { adalah } \\ \text { proses }\end{array} \\ \text { pembelajaran } & \text { yang }\end{array}$ dilakukan oleh instruktur pada matakuliah Speaking English di kelas.

\section{Pendahuluan}

a. Kegiatan ini diawali dengan greeting (salam pembuka) yang dilakukan dosen atau instruktur matakuliah Speaking English kepada mahasiswa di kelas. Suasana kelas menjadi berbeda dengan sebelumnya karena pada tahap ini dosen memutar soft musik dan materi yang dibahas oleh dosen atau instruktur di temple didinding kelas. Dosen menyapa mahasiswa pada awal kegiatan pembelajaran ini dengan menggunakan bahasa inggris, seperti berikut ini: Teacher: good morning students?

Students: good morning sir.

Teacher: how are you today?

Students: fine.

Teacher: thank you.

Setelah menyapa semua mahasiswa dikelas, maka dosen atau instruktur menginformasikan topik 


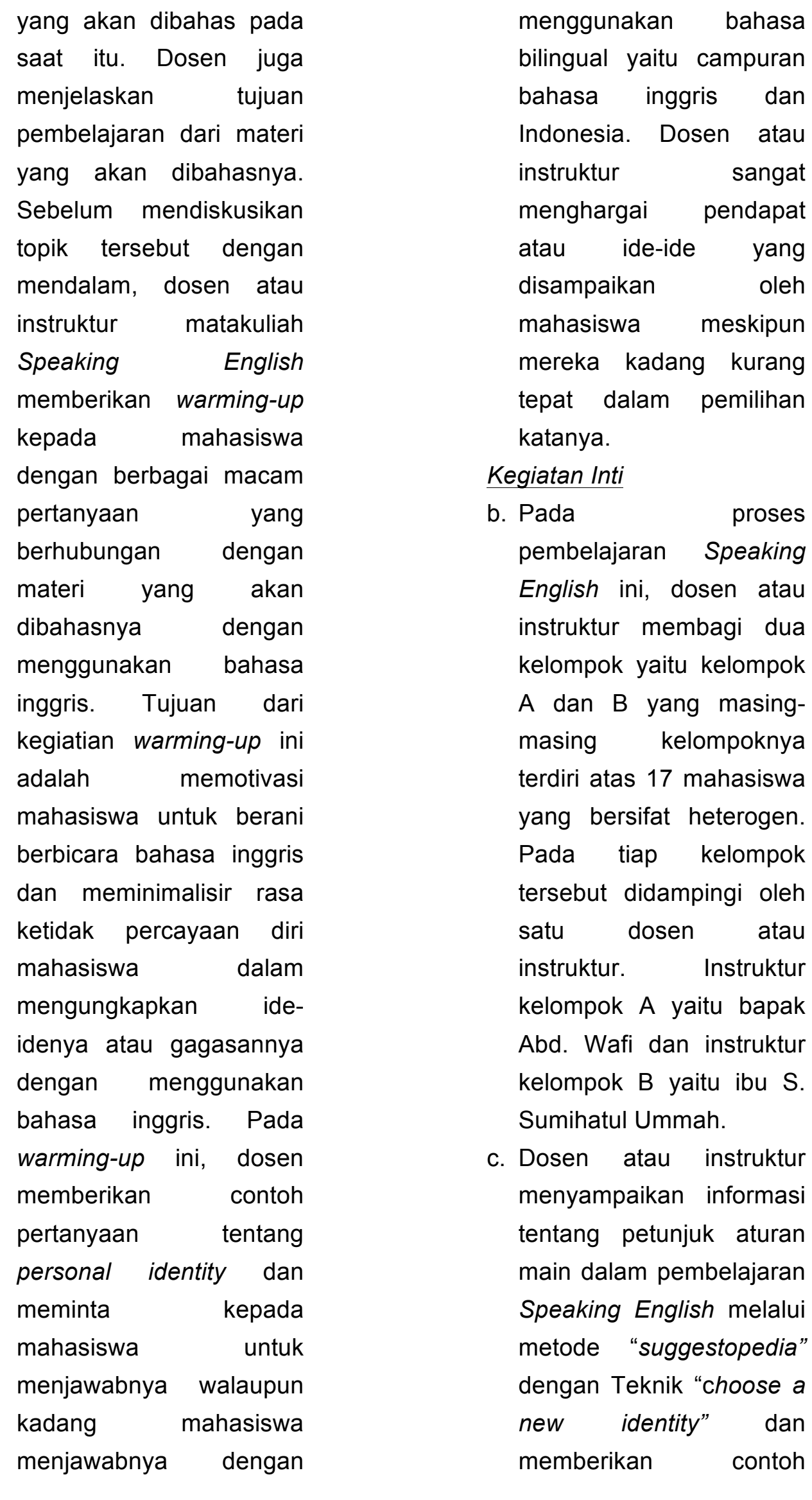


pertanyaan dan jawaban kepada mahasiswa pada saat berbicara bahasa inggris di kelas.

d. Dosen atau instruktur menjelaskan pada mahasiswa tentang materi "personal identity" yang di temple didinding kelas seperti:

- Nama-nama dalam bahasa target (English names), misalnya Jack, Richard, William, Barabara, Kate, Michael, Brithney, Anjela, dan sebagainya.

- Nama-nama pekerjaan (occupation), misalnya farmer, doctor, engineer, seller, teacher, lawyer, typist, lecturer, policeman, nurse, supervisor, dan sebagainya.

- Asal Negara (country), misalnya England, Singapore, Thailand, Australia, Mexico, Malaysia, dan sebagainya.

- Pertanyaan yang biasa digunakan dalam percakapan dengan topic personal identity, misalnya:

- May I introduce with you?
- What is your occupation?

- Where do you come from?

- Are you from England?

- Are you a teacher? etc.

e. Dosen atau instruktur meminta pada mahasiswa untuk memilih nama, pekerjaan, dan asal negara dalam bahasa target (inggris) yang berada pada poster yang ditempel didinding kelas tersebut. Dalam hal ini dosen atau instruktur mengatakan kepada mahasiswa bahwa mereka bebas memilih nama, pekerjaan, asal negara masing-masing sebagai identitas anda dalam kegiatan pembelajaran Speaking English.

f. Dosen atau instruktur mengucapkan setiap nama dan para mahasiswa mengulangi ucapan itu. Setelah itu, dosen atau instruktur meminta kepada mahasiswa untuk menyebutkan nama, pekerjaan, dan asal negara yang mana yang mereka pilih. 
g. Selanjutnya, dosen atau instruktur mengatakan kepada mahasiswa bahwa selama pross pembelajaran Speaking English ini berlangsung mereka akan menciptakan suatu biografi imajinatif megenai kehidupan identitas mereka yang baru itu.

h. Dosen atau instruktur menyapa setiap mahasiswa dengan menggunakan nama barunya dan mengajukan beberapa pertanyaan dalam bahasa Inggris mengenai jabatan atau pekerjaan barunya serta negara asalnya.

i. Dosen atau instruktur memberikan contoh percakapan bahasa inggris singkat dengan salah satu mahasiswa berdasarkan materi yang dijelaskannya yang ada atau ditempel di didinding kelas.

j. Dosen meminta mahasiswa melakukan kegiatan latihan Speaking English seperti yang telah dicontohkan dosen atau instruktur dengan teman sekelompoknya.

Kemudian dosen mengamati aktivitas mahasiswa

secara

bergantian dan membimbingnya jika ada kesulitan.

k. Setelah mahasiswa selesai melakukan kegiatan tersebut, dosen meminta kepada mahasiswa secara berpasangan untuk melakukan percakan bahasa inggris dengan teman sekelompoknya sesuai dengan aturan yang telah ditetapkan oleh dosen atau instruktur sebagai berikut:

$\checkmark$ Dosen atau instruktur memberikan small paper kepada semua mahasiswa dalam satu kelompok.

$\checkmark$ Dosen atau instruktur meminta kepada semua mahasiswa dalam satu kelompok tersebut untuk menulis identitas dirinya pada small paper tersebut.

Dosen atau instruktur meminta mahasiswa untuk berhitung bergantian dari nomor satu samapai tujuh belas sesuai dengan nomor urut tempat duduknya. Setelah itu, dosen menyuruh mahasiswa tersebut 
untuk menulis nomor yang telah disebutkan tadi pada pojok kanan atas dari small paper yang mereka meliki. Setelah itu, dosen meminta untuk mengumpulkannya.

Hal tersebut dilakukan agar kertas kecil yang dikumpulkan oleh tiap mahasiswa kepada masing-masing

instrukturnya tidak tertukar identitasnya dengan mahasiswa yang lain.

Dosen atau instruktur meminta dua mahasiswa dengan menyebutkan nomor urut yang ada pada small paper tadi untuk membuat percakapan dalam bahasa inggris secara oral didepan kelas. Pertanyaan dan jawaban yang diucapkan oleh mahasiswa tersebut harus berdasarkan pada identitas baru mereka. Kegiatan ini berlangsung secara bergantian dengan di damping oleh dosen atau instruktur masingmasing baik dari kelompok $\mathrm{A}$ atau $\mathrm{B}$.
Dosen memberikan reward (hadiah) pada sepasang mahasiswa yang dapat berbicara menggunakan bahasa inggris dengan benar dan lancar.

\section{Penutup}

I. Pembelajaran dilanjutkan dengan presentasi perwakilan dari masingmasing kelompok untuk memaparkan pengalaman mereka saat mengikuti permainan dalam matakuliah Speaking English.

m. Dosen memberikan evaluasi berupa tes Speaking English kepada setiap anggota kelompok untuk mengetahui pemahaman mahasiswa terhadap materi yang telah disampaikan.

n. Dosen membimbing mahasiswa

menyimpulkan hasil pembelajaran yang telah dilakukan.

o. Dosen memberikan penghargaan untuk kelompok terbaik dan mahasiswa teraktif dalam kelas.

\section{Observasi (Observing)}

$\begin{array}{lr}\text { Selama } & \text { kegiatan } \\ \text { pembelajaran, } & \text { peneliti }\end{array}$




$$
\begin{aligned}
& \text { mengamati } \\
& \text { pembelajaran } \\
& \text { English. } \\
& \text { proses } \\
& \text { Speaking } \\
& \text { Pengamatan Pengelolaan } \\
& \text { Pengajaran Speaking }
\end{aligned}
$$

\section{Refleksi (Reflecting)}

Setelah tahap kegiatan perencanaan, tindakan dan pengamatan selesai, maka diperoleh gambaran tentang kekurangan yang terjadi pada siklus I sebagai berikut:

a. Dosen kurang memberikan bimbingan kepada mahasiswa yang kesulitan dalam berbicara bahasa inggris. Hal ini disebabkan karena jumlah mahasiswa yang banyak yaitu 34 orang dan hanya dibagi dua kelompok yang masing-masingnya terdiri atas 17 mahasiswa. Sedangkan waktu yang disediakan hanya 100 menit, sehingga dosen kurang mengkafer dalam membimbing mahasiswa.

b. Dosen kurang memberikan bimbingan kepada mahasiswa pada waktu mempresentasikan pengalaman mengikuti matakuliah Speaking English dengan menggunakan metode suggestopedia.

c. Mahasiswa kurang antusias, karena banyak mahasiswa yang bergurau selama pembelajaran Speaking English sehingga kondisi kelas agak ramai.

d. Sebagian kecil mahasiwa kurang antusias dalam mengikuti proses pembelajaran Speaking English dengan menggunakan metode suggestopedia ini. Hal tersebut terjadi mungkin karena suasana belajar yang cukup relatif berbeda dengan sebelumnya.

Berdasarkan hasil refleksi pada siklus ke-l, peneliti menemukan banyak kekurangan-kekurangan yang terjadi pada siklus pertama di atas yang nantinya akan dijadikan masukan untuk diperbaiki 


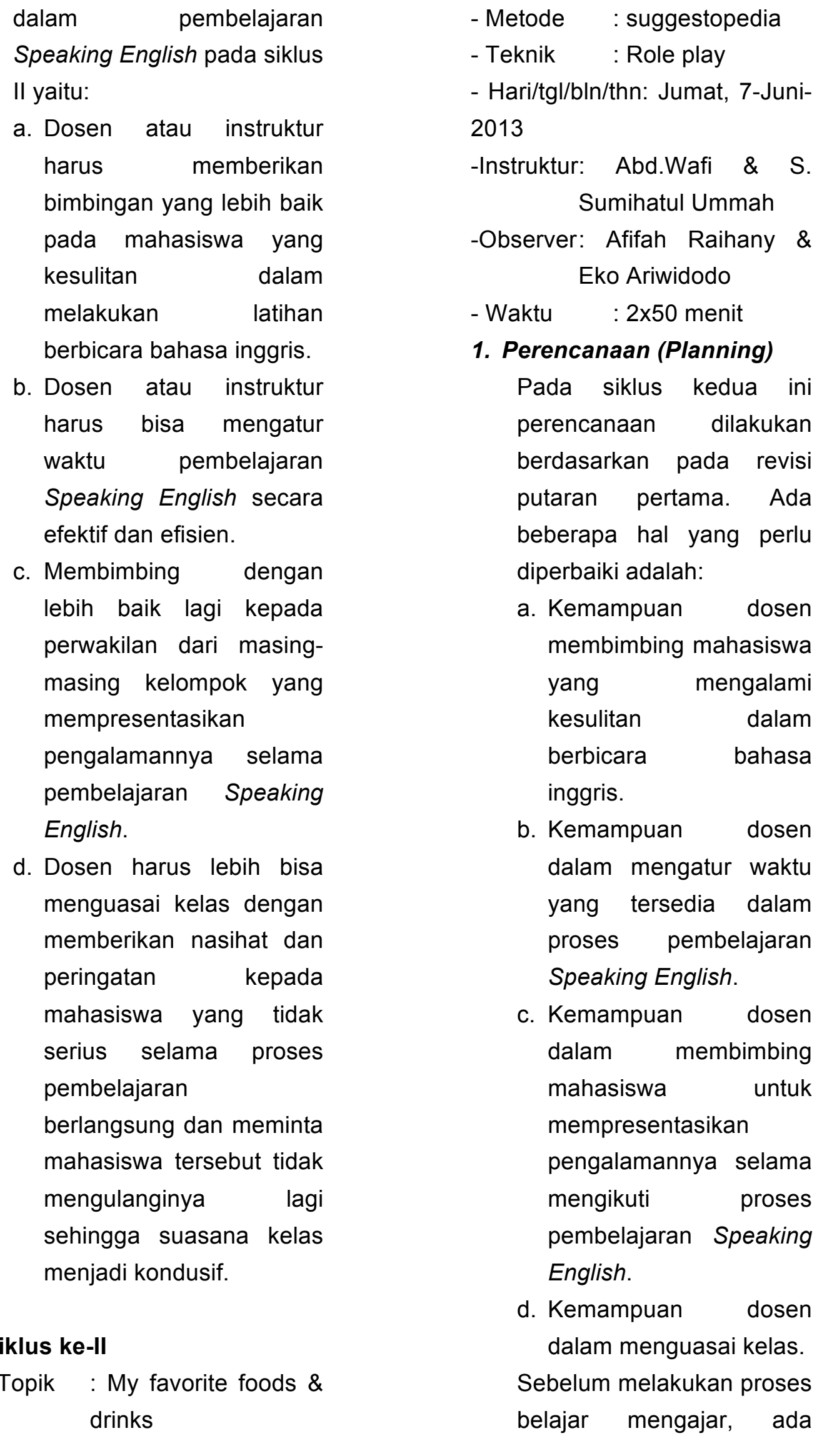


beberapa hal yang harus dipersiapkan diantaranya materi yang akan diajarkan dengan topik "my favorite foods and drinks", rencana pelaksanaan pembelajaran (RPP), lembar evaluasi mahasiswa, lembar pengamatan proses pembelajaran Speaking English, dan media yang digunakan dalam proses pembelajaran Speaking English.

\section{Tindakan (Acting)}

Pada tahap ini, penerapan metode suggestopedia diterapkan secara kolaboratif dengan dosen pengampu matakuliah Speaking English pada mahasiswa semester II-E TBI STAIN Pamekasan. Sedangkan observernya adalah ibu Afifah Raihany dan bapak Eko Ariwidodo (teman/dosen sejawat pada TBI STAIN Pamekasan). Tugas dari observer disini adalah mengamati proses pembelajaran yang dilakukan oleh instruktur pada matakuliah Speaking English di kelas.

Pendahuluan
a. Dosen
membuka pertemuan ini dengan greeting dulu pada

semua mahasiswa yang ada di kelas.

b. Dosen atau instruktur mengabsen mahasiswa semester II-E TBI STAIN Pamekasan.

c. Dosen atau instruktur menyampaikan tujuan pembelajaran Speaking English dengan topik "my favorite foods and drinks".

d. Dosen atau instruktur memberikan warming-up tentang materi yang di bahasnya pada saat itu dengan diiringi musik lembut sehingga tercipta suasana yang relaks dan nyaman. Kegiatan ini dilakukan oleh dosen atau instruktur selama kurang lebih 10 menit.

e. Pada kegiatan warmingup ini, dosen atau instruktur menunjukkan dua gambar yang berbeda kepada mahasiswa yaitu gambar makanan (pizza) dan minuman (orange juice). Setelah itu, dosen atau instruktur menanyakan kepada mahasiswa tentang makanan dan minuman apa yang paling mereka sukai. Mahasiswa meresponnya dengan 
semangat pertanyaan yang disampaikan oleh dosen atau instruktur tersebut.

\section{Kegiatan inti}

f. Dosen atau instruktur membagi mahasiswa semester II-E TBI STAIN Pamekasan dalam dua grup, yaitu grup A (S. Sumihatul Ummah) dan grup B (bapak Abd.Wafi). Masingmasing grup terdiri atas 17 mahasiswa secara heterogen.

g. Dosen atau instruktur menjelaskan materi yang dibahasnya dengan menunjukkan berbagai macam makanan dan minuman dalam bahasa inggris yang ada pada poster di dinding kelas. Contoh makanan dan minuman sebagai berikut:

\begin{tabular}{|c|l|l|}
\hline $\begin{array}{c}\mathbf{N} \\
\mathbf{o}\end{array}$ & Foods & Drinks \\
\hline Pizza & $\begin{array}{l}\text { Orange } \\
\text { juice }\end{array}$ \\
\hline 2. & Meatball & $\begin{array}{l}\text { Rainbow } \\
\text { ice }\end{array}$ \\
\hline 3. & $\begin{array}{l}\text { Fried } \\
\text { rice }\end{array}$ & $\begin{array}{l}\text { Coca- } \\
\text { cola }\end{array}$ \\
\hline 4. & $\begin{array}{l}\text { Fried } \\
\text { chicken }\end{array}$ & $\begin{array}{l}\text { Caffe } \\
\text { milk }\end{array}$ \\
\hline
\end{tabular}

\begin{tabular}{|c|l|l|}
\hline 5. & $\begin{array}{l}\text { Humbur } \\
\text { ger }\end{array}$ & Tea \\
\hline 6. & Spagetty & $\begin{array}{l}\text { Avocad } \\
\text { o juice }\end{array}$ \\
\hline 7. & Omlet & $\begin{array}{l}\text { Cappucc } \\
\text { ino caffe }\end{array}$ \\
\hline
\end{tabular}

h. Dosen atau instruktur meminta salah satu mahasiswa

membacakan contoh percakapan bahasa inggris singkat dengan topik "my favorite foods and drinks". Dalam hal ini, dosen atau instruktur berperan sebagai John dan seorang mahasiswa berperan sebagai Mathiew.

i. Dosen atau instruktur menyampaikan

informasi tentang macam-macam pertanyaan dan jawabannya yang biasa digunakan dalam percakapan bahasa inggris berdasarkan topik yang dibahas.

j. Dosen atau instruktur menanyakan secara lisan kepada mahasiswa dengan menggunakan bahasa Inggris tentang macam-macam makanan dan minuman favoritnya John dan Mathiew berdasarkan 


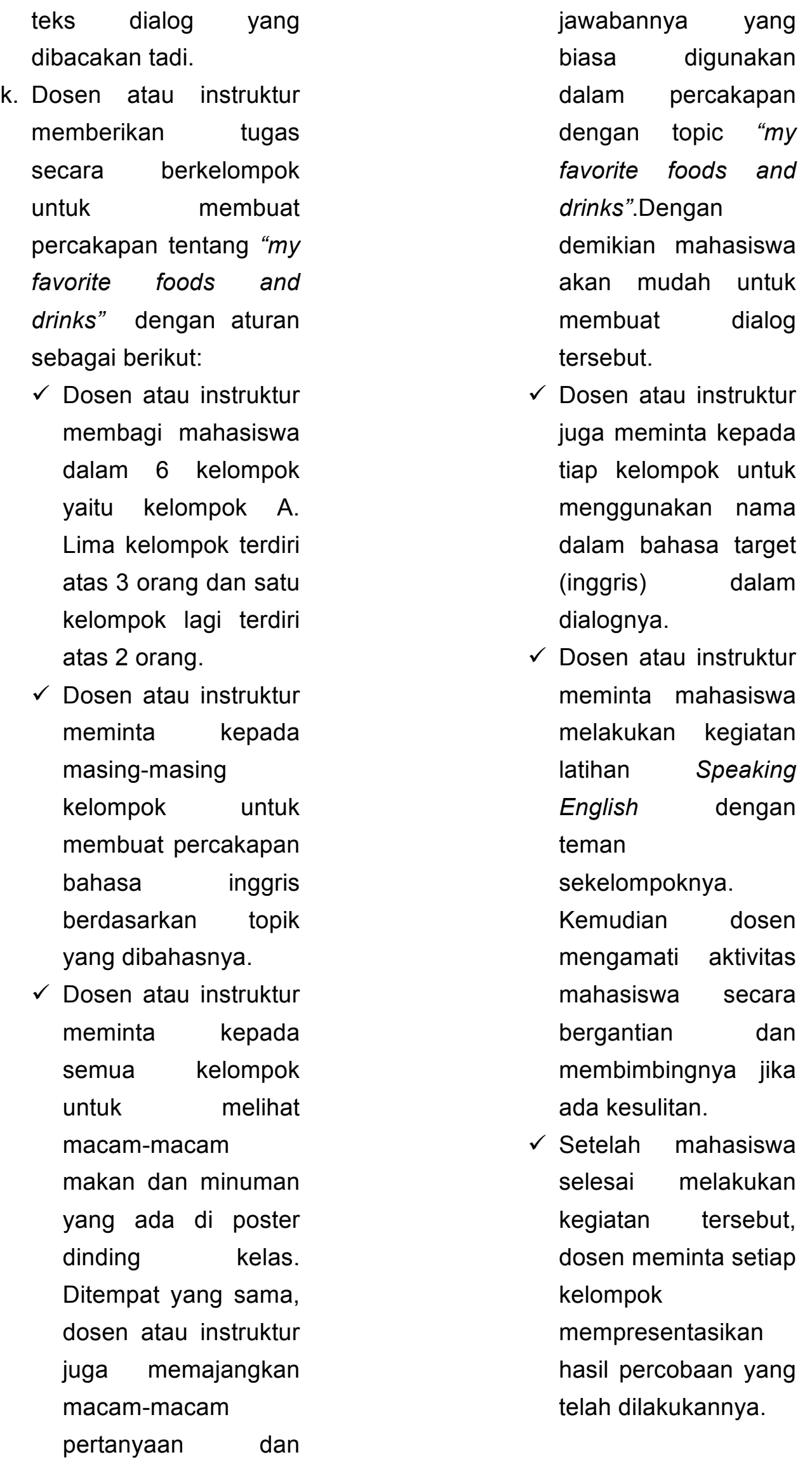


Dosen atau instruktur meminta kepada tiap kelompok untuk mengumpulkan dialog yang telah mereka buat kemudian memanggilnya tiap kelompok untuk tampil di depan kelas tanpa membaca teks dialog.

I. Dosen atau instruktur memberi reward (hadiah) kepada mahasiswa yang dapat melaksanakan kegiatan Speaking English paling benar dan lancar.

Penutup

m. Dosen atau instruktur memberikan evaluasi berupa tes Speaking English kepada setiap anggota kelompok untuk mengetahui pemahaman mahasiswa terhadap materi yang telah disampaikan.

n. Dosen atau instruktur membimbing mahasiswa untuk menyimpulkan hasil pembelajaran yang telah dilakukan.

o. Dosen atau instruktur memberikan

penghargaan untuk kelompok terbaik dan mahasiswa teraktif di dalam kelas. p. Dosen atau instruktur meminta kepada semua mahasiswa untuk mempraktekkan

Speaking English dalam kehidupan sehari-hari agar supaya mahasiswa terbiasa dan berani untuk berbicara dengan menggunakan bahasa inggris.

q. Dosen atau instruktur menutup proses pembelajaran Speaking English dengan mengucapkan salam penutup (clossing).

\section{Observasi (Observing)}

Selama kegiatan belajar mengajar berlangsung, peneliti mengamati proses jalannya pembelajaran Speaking English dengan menggunakan metode suggestopedia yang dilakukan oleh dosen Speaking English. Hasil hasil rata-rata penilaian lembar pengamatan pengelolaan pengajaran Speaking English pada siklus kedua sebesar 2,89 dengan kategori baik.

\section{Refleksi (Reflecting)}

Setelah tahap pengamatan pada siklus II diperoleh gambaran sebagai berikut:

a. Dosen atau instruktur sudah dapat 
memberikan bimbingan

secara merata kepada mahasiswa yang ada pada tiap kelompok yang mengalami kesulitan dalam pembelajaran Speaking English.

b. Dosen atau instruktur sudah dapat memberikan bimbingan kepada mahasiswa pada waktu mempresentasikan percakapannya dalam mengikuti mata kuliah Speaking English dengan menggunakan metode suggestopedia.

c. Dosen atau instruktur sudah dapat mengatur waktu yang tersedia dalam proses pembelajaran Speaking English dengan efektif dan efisien sehingga proses pembelajaran Speaking English selesai sesuai dengan waktu yang telah ditentukan.

d. Dosen atau instruktur sudah lebih baik dalam menguasai kelas walaupun masih ada mahasiswa yang bergurau dan tidak serius selama pembelajaran Speaking
English berlangsung di dalam kelas.

Berdasarkan dari hasil refleksi pada siklus ke-II, peneliti masih menemukan adanya kekurangankekurangan yang terjadi pada siklus kedua diatas yang nantinya akan dijadikan masukan untuk diperbaiki dalam pembelajaran Speaking English pada siklus ke-III yaitu:

a. Dosen atau instruktur harus lebih serius lagi membimbing mahasiswa dalam proses pembelajaran mata kuliah Speaking English dengan menggunakan metode suggestopedia agar supaya mahasiswa lebih semangat dan berani untuk berbicara dengan menggunakan bahasa inggris.

b. Dosen atau instruktur lebih baik lagi dalam membimbing kelompok yang melakukan presentasi.

c. Dosen atau instruktur berusaha lebih keras menegur mahasiswa yang sering bergurau dan tidak serius selama proses pembelajaran Speaking English di 
dalam kelas bahkan jika diperlukan memberikan sanksi agar tidak mengulangi lagi.

\section{Siklus ke-III}

- Topik : Future Plan (vacation, weekend, and party)

- Metode : suggestopedia

- Teknik : Secondary activation

- Hari/tgl/bln/thn: Jumat, 14Juni-2013

-Instruktur : Abd.Wafi \& S. Sumihatul Ummah

-Observer : Afifah Raihany \& Eko Ariwidodo

- Waktu : 2x50 menit

\section{Perencanaan (Planning)}

Pada siklus III ini, perencanaan dilakukan berdasarkan revisi pada siklus II. Yang perlu diperbaiki adalah kemampuan dosen dalam membimbing mahasiswa dalam proses pembelajaran Speaking English dan menangani mahasiswa yang melakukan tindakan menyimpang atau melanggar. Sebelum melaksanakan proses belajar mengajar, ada beberapa hal yang harus dipersiapkan diantaranya materi yang akan diajarkan dengan topik future plan (vacation, weekend, and party), rencana

pelaksanaan

pembelajaran

(RPP),

Evaluasi mahasiswa, lembar pengamatan pembelajaran Speaking English, dan media yang akan digunakan dalam pembelajaran

Speaking English.

\section{Tindakan (Acting)}

\section{Pendahuluan}

a. Pada awal pembelajaran dosen atau instruktur membuka proses pembelajaran dengan mengucapkan salam (greeting) kepada semua mahasiswa semester II-E TBI STAIN Pamekasan.

b. Dosen atau instruktur mengabsen mahasiswa semester II-E TBI STAIN Pamekasan

c. Dosen atau instruktur menginformasikan

kepada mahasiswa tentang toppik yang akan dibahasnya dalam proses pembelajaran Speaking English.

d. Dosen atau instruktur menyampaikan tujuan pembelajaran sesuai dengan topik yang akan dibahasnya.

e. Dosen atau instruktur memberikan warming-up yang berhubungan dengan topik pembelajaran Speaking 
English.memotivasi

mahasiswa. Pada

kegiatan warming-up ini

dilakukan dengan

memberikan pertanyaan

tentang future plan

(vacation, weekend, and

party) kepada mahasiswa.

Kegiatan ini diberikan

oleh dosen Speaking

English kepada

mahasiswa di dalam kelas

sebelum materi speaking

English dimulai.

\section{Kegiatan inti}

f. Dosen atau instruktur memberikan contoh rencana yang biasa dilakukan seseorang pada saat liburan, akhir minggu, dan pesta dengan menggunakan bahasa inggris.

g. Dosen atau instruktur meminta kepada salah satu mahasiswa untuk menjadi partnernya dalam percakapan (menjawab pertanyaan dari dosen) bahasa inggris dengan topik yang telah ditentukan.

h. Dosen atau instruktur meminta kepada mahasiswa untuk melihat macam-macam gambar kegiatan yang dilakukan seseorang pada saat liburan, akhir pekan, dan pesta di dinding kelas.

Dalam hal ini, dosen sambil membimbing mahasiswa tersebut dalam kegiatan ini.

i. Dosen atau instruktur meminta kepada mahasiswa untuk kembali pada tempat duduknya masing-masing dan membuat rencana pada saat liburan, akhir minggu, dan pesta dalam bentuk tulisan berbahasa inggris.

j. Dosen atau meminta kepada mahasiswa untuk mendiskusikannya dengan teman laiannya atau bertanya langsung kepada dosen jika ada hal yang sulit atau tidak mengerti.

k. Dosen atau instruktur menyampaikan informasi tentang petunjuk aturan main dalam pembelajaran Speaking English melalui metode suggestopedia pada topik "future plan (vacation, weekend, and party)" dan memberikan contoh pertanyaan dan jawaban kepada mahasiswa pada saat berbicara bahasa inggris di kelas.

I. Dosen meminta kepada mahasiswa untuk berlatih 
berbicara bahasa inggris kurang selama 15 menit secara berpasangan berdasarkan contoh yang telah diberikan oleh dosen tersebut.

$m$. Dosen atau instruktur meminta kepada semua mahasiswa untuk berdiri guna melatih keterampilan berbicara bahasa inggris mereka dengan memberikan permainan. Aturan permainan sebagai berikut:

$\checkmark$ Dosen atau instruktur melemparkan sebuah bola kepada salah satu mahasiswa. Kemudian, bagi mahasiswa yang mendapatkan bola tersebut maka dialah yang harus menjawab pertanyaan yang diberikan oleh dosen dengan menggunakan bahasa inggris. Pertanyaan dosen tersebut bedasarkan pada topik pembelajaran

Speaking English yang telah dijelaskan oleh dosen.

$\begin{array}{lr}\checkmark \text { Mahasiswa } & \text { yang } \\ \text { pegang } & \text { bola } \\ \text { permainan diminta } & \text { dintuk melemparkan }\end{array}$

bola tersebut kepada teman lainnya setelah percakapan dengan dosennya selesai.

$\checkmark$ Mahasiswa yang melempar bola ke salah satu temannya diminta untuk memberikan

pertanyaan dalam bahasa inggris sesuai dengan topik yang dibahas kepada penerima bola. Dalam permainan ini, Antara pelempar bola dan penerima bola akan berbagi cerita dalam bentuk tanya jawab dengan menggunakan bahasa inggris tentang rencana masingmasing yang akan dilakukan pada saat liburan, akhir pekan, dan pesta.

Setelah keduanya
selesai berbicara,
kemudian mahasiswa
penerima bola tadi
melemparkan bolanya
ke teman yang lainnya
lagi sampai semua
mahasiswa
mendapatkan
kesempatan untuk
berbicara dengan
menggunakan bahasa
inggris. Pada hal ini,


maka tercipta lagi hubungan komunikasi dengan menggunakan bahasa inggris antara pelempar bola dan penerima bola seperti kegiatan sebelumnya. Pada saat kegiatan ini berlangsung, soft music tetap diputar hingga akhir proses pembelajaran.

n. Dosen atau instruktur memberi reward (hadiah) kepada mahasiswa yang dapat melaksanakan kegiatan Speaking English paling benar dan lancar..

\section{Penutup}

o. Dosen atau instruktur memberikan evaluasi berupa tes Speaking English kepada mahasiswa untuk mengetahui pemahaman mahasiswa terhadap materi yang telah disampaikan.

p. Dosen atau instruktur membimbing mahasiswa untuk menyimpulkan hasil pembelajaran Speaking English yang telah dilakukan.

q. Dosen atau instruktur memberikan penghargaan untuk kelompok terbaik dan mahasiswa teraktif di dalam kelas.

r. Dosen atau instruktur menyarankan kepada mahasiswa agar sering melakukan latihan berbicara bahasa inggris dengan temannya dalam topik yang berbeda.

s. Dosen atau instruktur meminta kepada mahasiswa untuk dapat mengaplikasikan materi yang di dapat pada saat itu dalam kehidupan sehari-hari.

t. Dosen atau instruktur mengakhiri proses pembelajaran Speaking English dengan mengucapkan salam penutup (clossing).

\section{Observasi (Observing)}

Selama kegiatan belajar mengajar berlangsung, peneliti mengamati proses jalannya penerapan model pembelajaran Speaking English dengan menggunakan metode suggestopedia yang dilakukan oleh dosen Speaking English. hasil pengelolaan pengajaran Speaking English sudah dilakukan semua dan hasil rata-rata pada pertemuan ketiga sebesar 3,62 dengan kategori sangat baik. 


\section{Refleksi (Reflecting)}

Setelah tahap kegiatan dan pengamatan pada siklus III diperoleh gambaran sebagai berikut:

a. Dosen

sudah

membimbing mahasiswa dengan baik dalam proses pembelajaran matakuliah Speaking English dengan menggunakan metode suggestopedia.

b. Presentasi kelompok sudah berjalan dengan baik.

c. Penanganan mahasiswa yang tidak serius mengikuti pembelajaran Speaking English sudah baik dibuktikan dengan kondisi mahasiswa yang sudah kondusif dan mahasiswa antusias dalam mengikuti pembelajaran.

Pada siklus ke-III ini pelaksanaan pembelajaran Speaking English yang dilakukan oleh dosen dengan menggunakan metode suggestopedia berjalan dengan baik, di mana semua kekurangan pada siklus pertama dan kedua dapat teratasi dengan baik. Namun dosen masih perlu meningkatkan kegiatan latihan secara efektif dan tepat waktu terutama agar kemampuan psikomotorik mahasiswa meningkat serta hasil yang dicapai akan menjadi lebih baik. Revisi ini digunakan untuk pembelajaran Speaking English selanjutnya jika dilakukan dengan metode yang sama.

Berdasarkan pada tabel penilaian pembelajaran Speaking English tiap siklus mengalami peningkatan. Pada siklus I sebesar 1,78 dengan kategori cukup, siklus II sebesar 2,89 dengan kategori baik, dan siklus III sebesar 3,62 dengan kategori sangat baik.

2. Peningkatan

Keterampilan

\section{Berbicara Bahasa Inggris} Dengan Metode Suggestopedia.

> Hasil dan Analisis Penilaian Kinerja Speaking English Skill Mahasiswa

Untuk mengetahui peningkatan keterampilan berbicara bahasa inggris pada mahasiswa semester II-E TBI STAIN Pamekasan, peneliti menilai kinerja Speaking English mahasiswa tersebut berdasarkan aspek yang dinilai, antara lain kelancaran (fluency), penggunaan kosa kata (vocabulary), struktur kalimat (structure), kejelasan ujaran (comprehensibility), 
pemahaman

(listening),

menyimak

language

pronunciation

performance. Dari hasil dan

analisis penilaian kinerja

Speaking English mahasiswa

selama kegiatan belajar

mengajar berlangsung, dapat

disimpulkan bahwa kinerja

mahasiswa semakin baik pada

setiap siklusnya, mulai dari

siklus I sampai siklus III.

Kinerja mahasiswa dalam kegiatan Speaking English di kelas yang menonjol pada siklus I adalah struktur kalimat (structure) dengan nilai $85,2 \%$, sedangkan pada siklus II yang menonjol adalah kejelasan ujaran (comprehensibility) $88,2 \%$ dan vocabulary sebesar $88,2 \%$, dan siklus III yang menonjol adalah kelancaran (fluency) $91,2 \%$. Persentase kinerja mahasiswa dalam pembelajaran Speaking English dengan menggunakan metode suggestopedia dapat memperbaiki kinerja mahasiswa pada setiap siklus seperti terlihat pada tabel di bawah ini:

Tabel 1. Frekuensi Kinerja Mahasiswa Pada Tiap Siklus

(Speaking English Skill)

\begin{tabular}{|c|c|c|c|c|c|c|c|}
\hline \multirow{2}{*}{ Skor } & Kategori & \multicolumn{2}{|c|}{ Siklus I } & \multicolumn{2}{c|}{ Siklus II } & \multicolumn{2}{c|}{ Siklus III } \\
\cline { 3 - 8 } & $\begin{array}{c}\text { Rerata } \\
\text { frekuens } \\
\mathbf{i}\end{array}$ & $\mathbf{\%}$ & $\begin{array}{c}\text { Rerata } \\
\text { frekuens } \\
\mathbf{i}\end{array}$ & $\mathbf{\%}$ & $\begin{array}{c}\text { Rerata } \\
\text { frekuens } \\
\mathbf{i}\end{array}$ & $\mathbf{\%}$ \\
\hline 1 & Kurang & 15,87 & 46,69 & 0,00 & 0,00 & 0,00 & 0,00 \\
\hline 2 & Cukup & 20,13 & 59,19 & 25,87 & 76,10 & 2 & 5,88 \\
\hline 3 & Baik & 0,00 & 0,00 & 14,25 & 41,91 & 26,5 & 77,94 \\
\hline 4 & $\begin{array}{c}\text { Sangat } \\
\text { baik }\end{array}$ & 0,00 & 0,00 & 0,00 & 0,00 & 12,13 & 35,66 \\
\hline
\end{tabular}

Dari tabel di atas, dapat dilihat bahwa persentase kinerja mahasiswa yang diperoleh juga semakin meningkat pada setiap siklus, dimana pada siklus I persentase sebesar 59,19\% dengan kategori cukup, siklus II sebesar $76,10 \%$ dengan kategori cukup, dan pada siklus III sebesar $77,94 \%$ dengan kategori baik. Sedangkan standar ketercapaian kinerja mahasiswa pada pembelajaran
Speaking English jika mahasiswa memperoleh nilai $65 \%$ dari total skor tertinggi (32) yaitu 21. Sedangkan standar ketercapaian kelas diperoleh jika terdapat $85 \%$ mahasiswa telah mencapai standar ketercapaian kinerja mahasiswa. Dari penjelasan ini, diperoleh tabel standar ketercapaian kinerja mahasiswa pada setiap siklusnya adalah sebagai berikut: 
Tabel 2. Ketercapaian Mahasiswa Tiap Siklus

\begin{tabular}{|c|c|c|c|c|c|c|}
\hline \multirow{2}{*}{$\begin{array}{c}\text { No } \\
\text { Respon } \\
\text { den }\end{array}$} & \multicolumn{2}{|r|}{ Siklus I } & \multicolumn{2}{|c|}{ Siklus II } & \multicolumn{2}{|c|}{ Siklus III } \\
\hline & Skor & Keterangan & Skor & Keterangan & Skor & Keterangan \\
\hline 1 & 10 & Tidak tuntas & 19 & tidak tuntas & 19 & tidak tuntas \\
\hline 2 & 11 & Tidak tuntas & 21 & tuntas & 27 & tuntas \\
\hline 3 & 12 & Tidak tuntas & 18 & tidak tuntas & 25 & tuntas \\
\hline 4 & 12 & Tidak tuntas & 23 & tuntas & 27 & tuntas \\
\hline 5 & 14 & Tidak tuntas & 17 & tidak tuntas & 28 & tuntas \\
\hline 6 & 15 & Tidak tuntas & 21 & tuntas & 22 & tuntas \\
\hline 7 & 11 & Tidak tuntas & 18 & tidak tuntas & 24 & tuntas \\
\hline 8 & 14 & Tidak tuntas & 23 & tuntas & 28 & tuntas \\
\hline 9 & 13 & Tidak tuntas & 21 & tuntas & 28 & tuntas \\
\hline 10 & 14 & Tidak tuntas & 17 & tidak tuntas & 28 & tuntas \\
\hline 11 & 10 & Tidak tuntas & 16 & tidak tuntas & 28 & tuntas \\
\hline 12 & 10 & Tidak tuntas & 23 & tuntas & 25 & tuntas \\
\hline 13 & 15 & Tidak tuntas & 19 & tidak tuntas & 25 & tuntas \\
\hline 14 & 14 & Tidak tuntas & 21 & tuntas & 25 & tuntas \\
\hline 15 & 15 & Tidak tuntas & 17 & tidak tuntas & 24 & tuntas \\
\hline 16 & 15 & Tidak tuntas & 24 & tuntas & 20 & tidak tuntas \\
\hline 17 & 15 & Tidak tuntas & 21 & tuntas & 20 & tidak tuntas \\
\hline 18 & 11 & Tidak tuntas & 17 & tidak tuntas & 20 & tidak tuntas \\
\hline 19 & 16 & Tidak tuntas & 17 & tidak tuntas & 20 & tidak tuntas \\
\hline
\end{tabular}

OKARA, Vol. 2, Tahun X, Nopember 2015 


\begin{tabular}{|c|c|c|c|c|c|c|}
\hline 20 & 13 & Tidak tuntas & 16 & tidak tuntas & 30 & tuntas \\
\hline 21 & 16 & Tidak tuntas & 18 & tidak tuntas & 26 & tuntas \\
\hline 22 & 16 & Tidak tuntas & 16 & tidak tuntas & 26 & tuntas \\
\hline 23 & 12 & Tidak tuntas & 18 & tidak tuntas & 27 & tuntas \\
\hline 24 & 13 & Tidak tuntas & 21 & tuntas & 27 & tuntas \\
\hline 25 & 9 & Tidak tuntas & 23 & tuntas & 20 & tidak tuntas \\
\hline 26 & 16 & Tidak tuntas & 17 & tidak tuntas & 30 & tuntas \\
\hline 27 & 12 & Tidak tuntas & 17 & tidak tuntas & 27 & tuntas \\
\hline 28 & 16 & Tidak tuntas & 17 & tidak tuntas & 28 & tuntas \\
\hline 29 & 12 & Tidak tuntas & 24 & tuntas & 27 & tuntas \\
\hline 30 & 16 & Tidak tuntas & 24 & tuntas & 26 & tuntas \\
\hline 31 & 16 & Tidak tuntas & 22 & tuntas & 20 & tidak tuntas \\
\hline 32 & 13 & Tidak tuntas & 22 & tuntas & 27 & tuntas \\
\hline 33 & 16 & Tidak tuntas & 17 & tidak tuntas & 20 & tidak tuntas \\
\hline 34 & 16 & Tidak tuntas & 18 & tidak tuntas & 29 & tuntas \\
\hline $\begin{array}{c}\text { Jumlah } \\
\text { mahasis } \\
\text { wa yg } \\
\text { tuntas }\end{array}$ & & 0 & & 15 & & 26 \\
\hline
\end{tabular}

Dari tabel di atas diperoleh bahwa persentase ketercapaian kelas semakin meningkat pada tiap siklus, dimana pada siklus I sebesar $0 \%$, siklus II sebesar $44,1 \%$, dan siklus III sebesar $76,4 \%$.

\section{Analisis Hasil Belajar Speaking English Mahasiswa}

Dari evaluasi (tes Speaking English) yang diberikan kepada mahasiswa, diperoleh nilai hasil belajar pada setiap siklus sebagai berikut:

Tabel 4.8 Hasil Belajar Speaking English Pada Setiap Siklus

\begin{tabular}{|l|l|c|c|}
\hline No & Siklus I & Siklus II & Siklus III \\
\hline
\end{tabular}




\begin{tabular}{|c|c|c|c|c|c|c|}
\hline Responden & Nilai & Ket & Nilai & Ket & Nilai & Ket \\
\hline 1 & 70 & $\mathrm{~T}$ & 70 & $\bar{T}$ & 75 & $\mathrm{~T}$ \\
\hline 2 & 55 & TT & 70 & $\overline{\mathrm{T}}$ & 85 & $\overline{\mathrm{T}}$ \\
\hline 3 & 50 & TT & 55 & $\mathrm{TT}$ & 65 & $\mathrm{~T}$ \\
\hline 4 & 55 & TT & 60 & $\overline{\mathrm{TT}}$ & 70 & $\overline{\mathrm{T}}$ \\
\hline 5 & 45 & TT & 55 & $\mathrm{~T} T$ & 55 & TT \\
\hline 6 & 75 & $\mathrm{~T}$ & 75 & $\mathrm{~T}$ & 85 & $\mathrm{~T}$ \\
\hline 7 & 75 & $\mathrm{~T}$ & 75 & $\mathrm{~T}$ & 80 & $\mathrm{~T}$ \\
\hline 8 & 70 & $\mathrm{~T}$ & 70 & $\mathrm{~T}$ & 70 & $\mathrm{~T}$ \\
\hline 9 & 70 & $\mathrm{~T}$ & 75 & $\mathrm{~T}$ & 80 & $\mathrm{~T}$ \\
\hline 10 & 60 & $\overline{T T}$ & 70 & $\bar{T}$ & 70 & $\bar{T}$ \\
\hline 11 & 75 & $\mathrm{~T}$ & 75 & $\bar{T}$ & 90 & $\bar{T}$ \\
\hline 12 & 50 & TT & 65 & $\bar{T}$ & 85 & $\bar{T}$ \\
\hline 13 & 45 & $\overline{T T}$ & 60 & $\mathrm{TT}$ & 60 & TT \\
\hline 14 & 60 & T'T & 60 & $\mathrm{TT}$ & 70 & $\mathrm{~T}$ \\
\hline 15 & 60 & T'T & 60 & TT & 60 & TT \\
\hline 16 & 60 & $\overline{T T}$ & 65 & $\bar{T}$ & 75 & $\mathrm{~T}$ \\
\hline 17 & 60 & T'T & 70 & $\mathrm{~T}$ & 70 & $\mathrm{~T}$ \\
\hline 18 & 60 & T'T & 65 & $\overline{\mathrm{T}}$ & 80 & $\mathrm{~T}$ \\
\hline 19 & 45 & TT & 55 & $\mathrm{~T}^{\mathrm{T} T}$ & 65 & $\mathrm{~T}$ \\
\hline 20 & 60 & TT & 70 & $\mathrm{~T}$ & 75 & $\mathrm{~T}$ \\
\hline 21 & 60 & TT & 70 & $\mathrm{~T}$ & 75 & $\mathrm{~T}$ \\
\hline 22 & 70 & $\mathrm{~T}$ & 65 & $\mathrm{~T}$ & 70 & $\mathrm{~T}$ \\
\hline 23 & 75 & $\mathrm{~T}$ & 75 & $\bar{T}$ & 85 & $\bar{T}$ \\
\hline 24 & 65 & $\mathrm{~T}$ & 65 & $\overline{\mathrm{T}}$ & 75 & $\overline{\mathrm{T}}$ \\
\hline
\end{tabular}




\begin{tabular}{|c|c|c|c|c|c|c|}
\hline 25 & 75 & $\mathrm{~T}$ & 55 & $\mathrm{TT}$ & 60 & $\mathrm{TT}$ \\
\hline 26 & 60 & $\mathrm{TT}$ & 65 & $\mathrm{~T}$ & 85 & $\mathrm{~T}$ \\
\hline 27 & 65 & $\mathrm{~T}$ & 70 & $\mathrm{~T}$ & 75 & $\mathrm{~T}$ \\
\hline 28 & 65 & $\mathrm{~T}$ & 70 & $\mathrm{~T}$ & 50 & $\mathrm{TT}$ \\
\hline 29 & 60 & $\mathrm{TT}$ & 60 & $\mathrm{TT}$ & 90 & $\mathrm{~T}$ \\
\hline 30 & 45 & $\mathrm{TT}$ & 55 & $\mathrm{TT}$ & 60 & $\mathrm{TT}$ \\
\hline 31 & 70 & $\mathrm{~T}$ & 75 & $\mathrm{~T}$ & 80 & $\mathrm{~T}$ \\
\hline 32 & 50 & $\mathrm{TT}$ & 70 & $\mathrm{~T}$ & 80 & $\mathrm{~T}$ \\
\hline 33 & 45 & $\mathrm{TT}$ & 60 & $\mathrm{TT}$ & 70 & $\mathrm{~T}$ \\
\hline 34 & 60 & $\mathrm{TT}$ & 65 & $\mathrm{~T}$ & 70 & $\mathrm{~T}$ \\
\hline
\end{tabular}

*Keterangan: $\mathrm{T}=$ tuntas, $\mathrm{TT}=$ tidak tuntas

Berdasarkan tabel di atas, hasil belajar mahasiswa pada siklus I yang tidak tuntas 21 mahasiswa sedangkan mahasiswa yang tuntas sebanyak 13 mahasiswa dengan persentase ketuntasan sebesar $38,23 \%$ dan nilai ratarata 60,73. Untuk hasil belajar mahasiswa pada siklus II yang tidak tuntas 11 mahasiswa, untuk mahasiswa yang tuntas sebanyak 23 mahasiswa dengan persentase ketuntasan sebesar $67,64 \%$ dan nilai ratarata 65,88 . Sedangkan untuk hasil belajar mahasiswa pada siklus III yang tidak tuntas 6 mahasiswa, untuk mahasiswa yang tuntas sebanyak 28 mahasiswa dengan persentase ketuntasan sebesar $82,35 \%$ dan nilai rata-rata 73,23.

\section{B. Pembahasan Hasil Penelitian}

Berdasarkan hasil analisis data pengelolaan pembelajaran Speaking English yang dilakukan oleh dosen pada siklus I diperoleh catatan bahwa dosen masih kurang dalam memberikan motivasi kepada mahasiswa, dosen kurang dalam membimbing mahasiswa dalam latihan Speaking English, dosen kurang dalam membimbing mahasiswa dalam mempresentasikan hasil latihan dan mahasiswa kurang antusias dalam mengikuti pembelajaran. Pada siklus II menunjukkan bahwa kekurangan pada siklus I sudah berkurang, tetapi 
belum seluruhnya. Pada siklus II dosen belum bisa mengatur waktu pembelajaran Speaking English dengan efektif dan efisien. D samping itu, dosen masih kurang membimbing mahasiswa ketika latihan Speaking English dan ketika presentasi serta antusias mahasiswa masih kurang dalam mengikuti pembelajaran Speaking English. Pada siklus III kekurangan pada siklus I dan siklus II sudah teratasi begitu pula penggunaan waktu yang tersedia. Pengelolaan pembelajaran yang baik ini ternyata relevan dengan kinerja mahasiswa pada saat melakukan proses pembelajaran Speaking English, dimana kinerja mahasiswa yang diperoleh semakin baik dari siklus I sampai siklus III.

Secara klasikal pada siklus I, II, dan III terdapat peningkatan nilai ketuntasan belajar mahasiswa yaitu ketuntasan kelas pada masingmasing siklus sebesar $38,23 \%$, $67,64 \%$ dan $82,35 \%$, sehingga dapat dikatakan bahwa penerapan metode suggestopedia dalam pembelajaran Speaking English dapat meningkatkan hasil belajar mahasiswa. Keberhasilan dosen dalam mengelola pengajaran Speaking English dengan menggunakan metode suggestopedia ini menunjukkan bahwa dosen mampu membimbing mahasiswa untuk aktif dalam kegiatan belajar mengajar sehingga dapat dikatakan bahwa dosen hanya sebagai fasilitator.

\section{Penutup}

Dari hasil analisis dalam penelitian dan pembahasan yang telah diperoleh melalui penerapan metode suggestopedia dalam pembelajaran Speaking English pada mahasiswa semester II-E TBI STAIN Pamekasan, dapat disimpulkan bahwa dari data yang telah dianalisis diperoleh hasil tentang pengelolaan pengajaran yang dilakukan dosen semakin baik dari siklus I sampai siklus III. Pada siklus I skor rata-ratanya sebesar 1,78 dengan kategori cukup, pada siklus II sebesar 2,89 dengan kategori baik, dan pada siklus III sebesar 3,62 dengan kategori sangat baik.

Sedangkan kinerja mahasiswa tiap aspeknya (mencakup accuracy, fluency, comprehensibility, delivering arguments, Vocabulary, pronunciation, grammar, dan language style) semakin baik pada setiap siklus I sampai siklus III. Kinerja mahasiswa tiap aspeknya dalam kegiatan Speaking English di kelas yang menonjol pada siklus I adalah grammar dengan nilai $85,2 \%$. Pada siklus II yang menonjol adalah kejelasan ujaran (comprehensibility) $88,2 \%$ dan vocabulary sebesar $88,2 \%$. Pada siklus III yang menonjol adalah kelancaran fluency sebesar 91,2\%. Untuk persentase frekuensi kinerja mahasiswa pada tiap siklusnya juga semakin meningkat, yaitu pada siklus I sebesar $55 \%$ dengan kategori cukup, 
siklus II sebesar $70 \%$ dengan kategori baik, dan pada siklus III sebesar $85 \%$ dengan kategori sangat baik.

Kesimpulan penelitian ini adalah kinerja mahasiswa dalam proses pembelajaran Speaking English dengan menggunakan metode suggestopedia semakin baik pada tiap siklusnya. Hal ini ditunjukkan dengan semakin meningkatnya persentase kinerja mahasiswa dari siklus I sampai siklus III. Mengingat pentingnya keterampilan berkomunikasi yang diperlukan dalam matakuliah Speaking English, maka masalah komunikasi perlu mendapat perhatian dari para dosen agar terus dikembangkan sesuai dengan materi pembelajaran yang berlangsung dan juga dapat dimulai dari semester awal. Metode suggestopedia termasuk salah satu metode TEFL yang jarang digunakan pada pembelajaran Speaking English dan diharapkan para dosen berani untuk menerapkannya dalam proses pembelajaran Speaking English sesuai dengan tujuan yang akan dicapai. Para dosen yang menerapkan metode suggestopedia ini hendaknya juga memperhatikan kelemahan-kelemahan yang ada dalam proses pembelajarannya agar dapat berhasil dengan lebih baik.

\section{Daftar Pustaka}

Depdiknas. 2002. Kurikulum Berbasis Kompetensi. Jakarta Pusat: Pusat Kirikulum Balitbang Diknas.

Larsen-Freeman, D. 1986. Techniques and Principles in Language Teaching. Oxford: Oxford University Press.

Latief, Adnan M. 2009. Penelitian Tindakan Kelas Pembelajaran Bahasa Inggris. Malang: Universitas Negeri Malang.

Latief, Adnan M. 2011. Research Methods on Language Learning an Introduction. Malang: Universitas Negeri Malang.

Mukhlis. 2000. Penelitian Tindakan Kelas. Pusat Sains MIPA Unesa

Setiyadi, A. Bambang, dkk. 2008. TEFL 2. Jakarta: Penerbit Universitas Terbuka.

Tarigan, Henry Guntur.2009. Metode Pengajaran Bahasa.Bandung: Angkasa Bandung.

Yoko, Rimy. 2008. Penelitian Tindakan Kelas sebagai Bentuk Pengembangan Profesi Guru. Yogyakarta: LPMP. 